\title{
The Discovery Learning Model with A Scientific Approach to Increase Science Learning Achievement of Students
}

\author{
Fiona Setyo Resmawati ${ }^{*}$, Prabowo, and Munasir \\ Physics Department, Universitas Negeri Surabaya, Ketintang, Surabaya 60231, East Java, Indonesia \\ *resmafiona93@gmail.com
}

\begin{abstract}
This study aims to describe the effectiveness of the discovery learning model with a scientific approach to the science learning of temperature and heat matter. Discovery learning model is a learning model that aims to train students in finding the concept independently in solving problems. This research uses one group pretest-posttest design. The subjects of the study included three classes of students of the Public school of 1 Krian class VIIC, VII-D, and VII-E in the second semester of the academic year 2017/2018. Data collection used observation, test, and questionnaire methods. Instruments used include the test results of learning as much as $\mathbf{2 0}$ items. The effectiveness of learning is evaluated from the value of $\mathrm{N}$-Gain which are class VII-C of 0.77 , class VII-D of 0.75 , and class VII-E of 0.75 from which each grade obtained high $\mathrm{N}$-Gain value. The affective and psychomotor learning outcomes were calculated percentage achievement. Student's response to learning by using the discovery learning method with scientific approach was very positive, $\mathbf{9 4 . 8 5 \%}$ responded well and $5.15 \%$ responded less well. Based on the findings of this study, it is concluded that the students' learning outcomes in both cognitive, affective, and psychomotor aspects have improved by using discovery learning with a scientific approach.
\end{abstract}

Keywords-Discovery Learning; Learning Outcomes; Scientific Approach.

\section{INTRODUCTION}

Science is one of the most important subjects that is always given at every level of education. Science learning in junior high school is not as a disciplined knowledge. Science is developed as an integrative subject of science that has the meaning of combining various aspects, namely cognitive, affective, and psychomotor domain. The science lesson in the 2013 curriculum is emphasized to use a scientific approach which includes observing, questioning, experimenting, associating and communicating [1].

Associated with science teaching process applied by the teacher has been still done conventionally. Teachers have not fully implemented learning actively and creatively to engage students. Science learning is still dominated by lecture and assignment methods. Learning that uses discovery learning model with a scientific approach to learners can encourage independence, curiosity, and investigations. Then learning assessments that emphasize more on performance and students understanding is based on the learning process on cognitive principles [2].

Discovery learning is relevant scientific approach designed so that students actively construct concepts, principles through stages of observing, formulating problems and hypotheses, collecting data, drawing conclusions and communicating concepts and principles that have been discovered. The scientific approach provides students with an understanding of various materials using a scientific approach. That information can come from anywhere does not depend on the direction of the teacher's information. Learning encourages students to find out from various sources through observation and not just being told [3].

\section{RESEARCH METHOD}

This study used a one-group pretest-posttest design. The subject of research using discovery learning model with scientific approach was the students of the Public school of 1 Krian in the semester of the academic year 2017/2018 with a limited number of students as many as 10 students for three classes. Test learning outcomes included the cognitive, affective, and psychomotor aspects of students individually and classically. The test of the product objectives used included the initial and final test given to the students on temperature and heat materials of 20 questions, affective ratings and psychomotor assessments assessed during the lesson. Data of pretest result and posttest of student knowledge was done by N-Gain analysis showing the difference of student's knowledge before and after. The final score was obtained from the student's cognitive score of $50 \%$, the effective value of the students by $30 \%$, and the student psychomotor score of $20 \%$ [4]. Students score above 75 was said to reach the minimum completeness criteria individually.

\section{RESULTS AND DISCUSSION}

\section{A. Results of the Effectiveness of the Discovery Learning Model with Scientific Approach \\ 1) Cognitive Aspects}

The results of data analysis of cognitive aspects of students after getting learning model of discovery learning with scientific approach of temperature and caloric material showed an increase in student learning outcomes is presented in Graphics 1. 
Graphic 1. Results of Improved Learning Outcomes

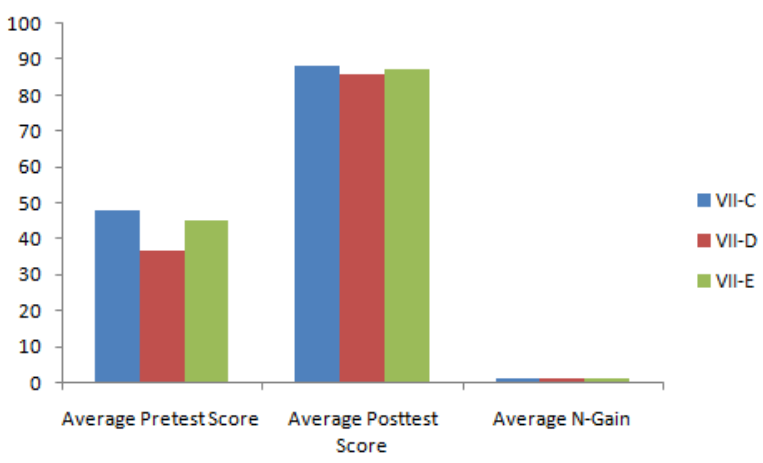

Based on Graphic 1, it could be seen that the score of increase (N-Gain) on the test result of students learning class VII-C, VII-D, and VII-E from applying learning result of discovery learning model with scientific approach had a positive effect on student learning result. The average N-Gain obtained was Based on Table 1, it can be seen that the score of increase (N-Gain) on the test result of students learning class VII-C, VII$\mathrm{D}$, and VII-E from applying learning result of discovery learning model with scientific approach had a positive effect on student learning result. The average N-Gain obtained was $0.75-0.77$ with high category [5]. In the opinion of [6] which stated that learning by using discovery learning model could improve student learning outcomes and provide a more meaningful learning experience for students. Discovery learning model applied [7] stated that learning discovery learning could improve learning outcomes and percentage mastery of students learning science.

\section{2) Affective Aspects}

Results of affective aspects of students in discovery learning with scientific approach is presented in Graphic 2.

Graphic 2. Learning Results of Affective Aspects

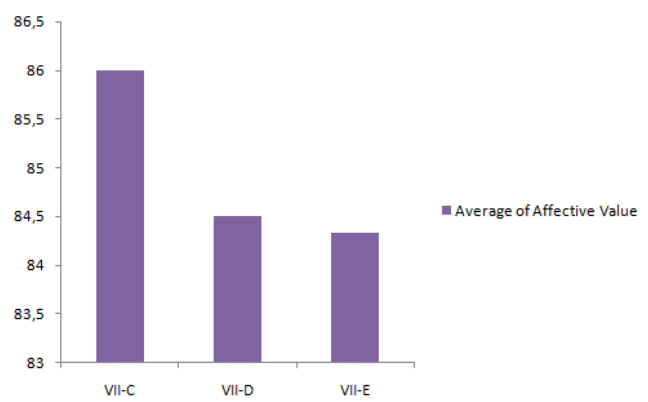

Based on Graphic 2, the affective final value score of grade VII-C students obtained an average score of 86 , while grade VIID students obtained an average score of 84.50, and grade VII-E students obtained an average score of 84.33. The affective aspect of students was in a good category. This indicated that each meeting had increased. In the opinion of [8] stated that the student's inability to behave in good character even though they were cognitively capable, but in good character was not necessarily able.
Discovery learning model of scientific approach influences student learning outcomes because syntax in data collection, data processing, and verification can shape student attitudes. Affective aspects achieved in research were assessment and determination of attitudes. Students were able to think of good or bad attitudes done by themselves and others. The material obtained by students from data collection and discussion forms the honest attitude of students in conducting experiments and answering the formulation of a predetermined problem so that students' disciplinary attitudes are formed. In addition, the data collection and discussion stages could foster greater curiosity about the concept of temperature and heat transfer in everyday life. Experiment activities at the verification stage emphasized students to have a sense of responsibility in the accuracy of the use of experimental tools related to the results of the experiment. Therefore, discovery learning models of scientific approaches to affective aspects can influence student learning outcomes.

3) Psychomotor Aspects

Psychomotor aspect result of student in discovery learning model with scientific approach in Graphic 3.

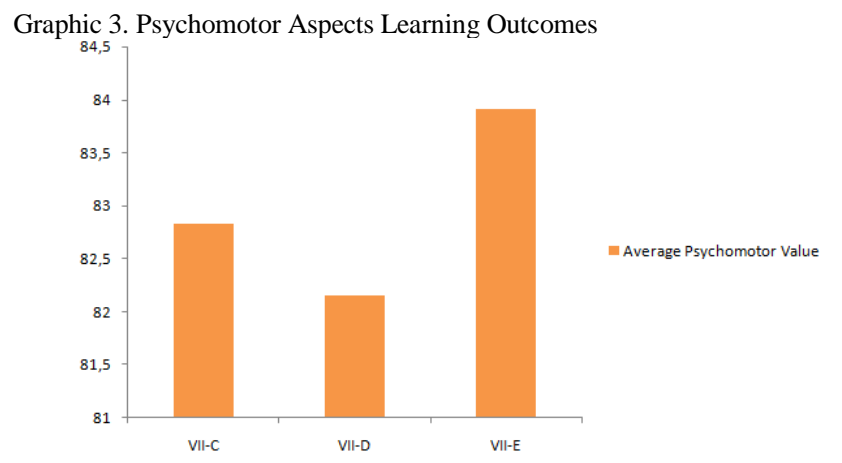

Based on Graphic 3, the result of the psychomotor final score of students of class VII-C obtained an average value of 82.83, the result of the psychomotor final score of class VII-D students obtained an average score of 82.16, and the result of psychomotor final score class VII- E obtained an average value of 83.91. Psychomotor aspects of students were in a good category. This indicated that every student meeting had increased. In the opinion of [9], the discovery learning model with a scientific approach could be done well. Students were helped to improve and increase the science process skills, elicited pleasure in students because of the growing sense of investigating and finding new things.

\section{4) Final Evaluation Learning Results}

The final assessment was done by combining students' cognitive, affective, and psychomotor values. The final value was obtained from the students' cognitive value of $50 \%$, the affective value of the students by $30 \%$, and the psychomotor value of students' by $20 \%$, so as to form a complete Indonesian human that was the nation's intellect, honesty, and performing. 
Graphic 4. Final Evaluation Learning Results

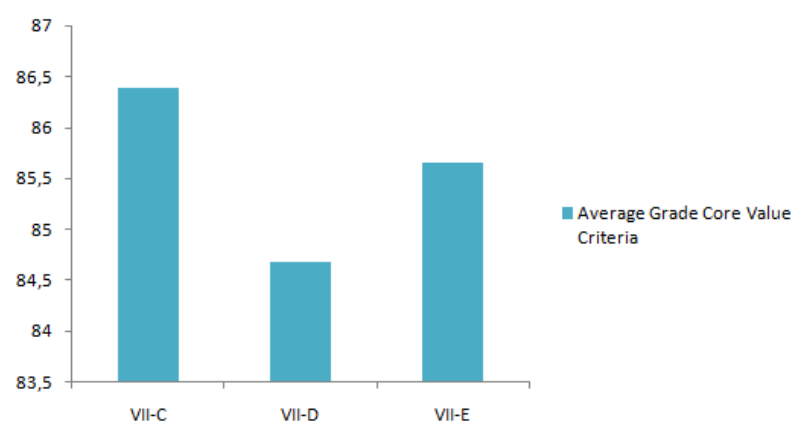

The results of this study were in line with previous research [10] that suggest this discovery learning model. There were significant differences in learning outcomes in the form of posttest students, both affective and psychomotor levels.

\section{B. Results of Student Response to Discovery Learning Model with Scientific Approach}

Results of student responses to teaching and learning activities in Graphic 5.

Graphic 5. Results of Student Response

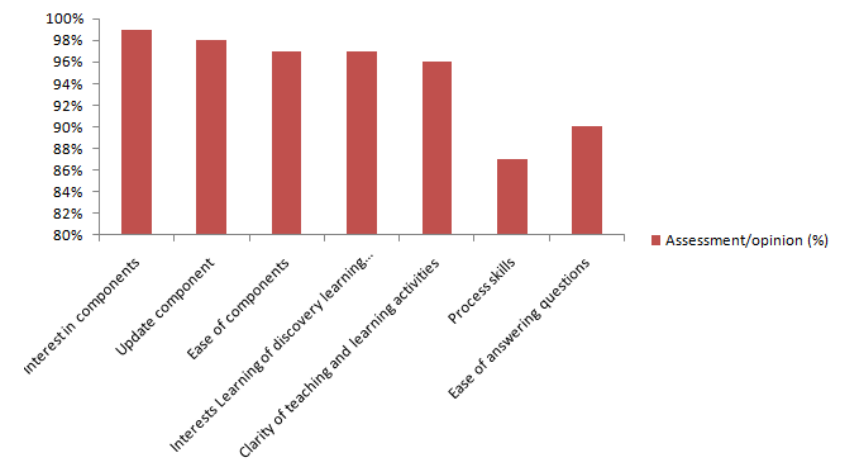

Based on the analysis of student response data on the components of science learning activities with the discovery learning model in Graphic 5, it can be seen that as many as $94.85 \%$ of students gave a positive response to the implementation of learning and learning tools developed and students enjoyed and received learning process using discovery learning model with scientific approach. It was supported by [10] which stated that discovery learning model with scientific approach was new and fun for students. Moreover, the students were also given learning opportunities and experiments in groups so that students enthusiastically learned to make problem formulation, formulated hypotheses, did scientific work, asked, expressed opinions, followed the learning process with passion, and had a sense of gratitude to God and responsibility for the task given.

\section{CONCLUSION}

Based on the results of research that had been done, it can be concluded that the learning outcomes of students of class VII-C, VII-D, and VII-E by applying learning model discovery learning with scientific approach gave a positive response. In the learning outcomes of each meeting was found that the average value of the final evaluation of students covering aspects of cognitive, affective, and psychomotor aspects was concluded in the complete criteria with a range of 84.68 to 86.39 .

\section{REFERENCES}

[1] Permendikbud, Jurnal Lampiran Peraturan Menteri Pendidikan dan Kebudayaan Republik Indonesia Nomor 65 Tahun 2013 tentang Standar Proses Pendidikan Dasar dan Menengah. Jakarta: Kemendikbud, 2013.

[2] A. G. Balim, "The Effect of Discovery Learning on Students' Success and Inquiry Learning Skills", Eigitim Arastirmalari-Eurasian Journal of Educational Research, 2009.

[3] Daryanto, Pendekatan Pembelajaran Saintifik Kurikulum 2013. Yogyakarta: Gava Media, 2014.

[4] Prabowo, "Pendidikan Fisika dalam Upaya Membentuk Manusia Indonesia Seutuhnya", Prosiding national conference $2^{\text {nd }}$ Lontar Physics Forum IKIP Semarang, 2013.

[5] R. Hake, Analyzing Change/Gain Score, 1999.

[6] M. Putrayasa, "Pengaruh Model Discovery Learning dan Minat Belajar Terhadap Hasil Belajar IPA Siswa”, Jurnal Mimbar Universitas Pendidikan Ganesha, 2014.

[7] E. L. P. Subari, "Implementasi Pembelajaran Inquiri Discovery Berorientasi NOS (Natural of Science) dalam Pembelajaran Gaya Sebagai Upaya Meningkatkan Hasil Belajar IPA", Jurnal Universitas Pendidikan Ganesha, 2011.

[8] S. S. Widiadnyana, "Pengaruh Model Discovery Learning Terhadap Pemahaman Konsep IPA dan Sikap Ilmiah Siswa SMP", e-Jurnal Pascasarjana Universitas Pendidikan Ganesha, 2014.

[9] E. Susanti, M. Jamhari, \& Sleeman, "Pengaruh Model Pembelajaran Discovery Learning Terhadap Keterampilan Proses Sains dan Hasil Belajar Siswa Kelas VIII IPA", Jurnal Sains dan Teknologi Tadulako, 2016.

[10] I. F. Azzahro, "Pengembangan Perangkat Pembelajaran Berbasis Discovery Learning Pada Materi Respirasi dan Fotosintesis Kelas VII SMP”, Jurnal Penelitian Pendidikan IPA Universitas Negeri Surabaya, 2014.

[11] S. P. Ihdi, "Pengaruh Model Pembelajaran Discovery Learning Terhadap Hasil Belajar Siswa dan Aktivitas Siswa", Jurnal Pendidikan Fisika Universitas Negeri Medan, 2017.

[12] W. V. Joolingen, "Cognitive tools for discovery learning”, International Journal of Artificial Intelligence in Education, 1999.

[13] M. Kadri \& Rahmawati, "Pengaruh Model Pembelajaran Discovery Learning Terhadap Hasil Belajar Siswa Pada Materi Pokok Suhu dan Kalor", Jurnal Ikatan Alumni Fisika Universitas Negeri Medan, 2015.

[14] D. Kurmalasari L. Sudarti, "Dampak Model Discovery Learning Terhadap Keterampilan Proses Sains dan Hasil Belajar IPA-Fisika di MTSN Jember”, Jurnal Pendidikan Fisika, 2015.

[15] W. Roihana, "Pengembangan Perangkat Pembelajaran IPA SMP Melalui Model Discovery Learning Pada materi Pemanasan Global Untuk Meningkatkan Hasil Belajar Siswa", Jurnal Pendidikan IPA Universitas Negeri Surabaya, 2015.

[16] R. Sintia, "Pengembangan LKS Model Discovery Learning Melalui Pendekatan Saintifik Materi Suhu dan Kalor", Jurnal Imu Kependidikan Universitas Lampung, 2015. 